\title{
Ammatillista huippuosaamista vaativilla kehittämistehtävillä
}

\author{
Kati Partanen ${ }^{1}$; Heli Wahlroos ${ }^{1}$ \\ 1) Savonia-ammattikorkeakoulu, PL 72, 74101 Iisalmi, etunimi.sukunimi@ savonia.fi
}

\begin{abstract}
Ylempi ammattikorkeakoulututkinto on ammatillista osaamista syventävä tutkinto, johon voi hakeutua alan korkeakoulututkinnon suorittaneet vähintään kolmen vuoden työkokemuksen jälkeen. Tutkintoohjelman painotukset voidaan valita ammattikorkeakoulun valinnan mukaan vastaten Eurooppalaisen tutkintojen viitekehyksen (EQF) tasoa 7. Savonia-ammattikorkeakoulun tarjoamasta Maaseudun kehittämisen tutkinto-ohjelmasta valmistutaan nimikkeellä Agrologi Ylempi AMK.
\end{abstract}

Maaseudun uudistuva työelämä vaatii erityisesti tiimityöskentely- ja johtamistaitoja sekä valmiutta vaativien kehittämistehtävien läpivientiin. Maaseudun kehittämisen tutkinto-ohjelman pedagogisena lähtökohtana on sosiokonstruktivismi, jossa oppiminen tapahtuu yhteisöllisesti aiempaa osaamista hyödyntäen, mikä sopii erinomaisesti ylempiin ammattikorkeakoulututkintoihin. Vahva yhteys työelämään ja alan kehittämiseen on motivoivaa. Esitellyssä koulutusmallissa opiskelija on vastuussa kehittämistehtävän tuloksista ensisijaisesti kohdeyritykselle, toissijaisesti tiiminsä jäsenille ja vasta viimeiseksi opintojakson opettajalle.

Opiskelijat toteuttavat ammatillisten opintojen aikana laajan maaseutuyrityksen kehittämistehtävän tiimityönä, jossa jäsenten osaamiset täydentävät toisiaan. Jokainen 4-5 hengen tiimi saa työstettäväkseen todellisen maaseutuyrityksen kehittämistehtävän, jonka työstäminen etenee kolmen eri opintojakson (á 5 op) aikana yhdessä kohdeyrityksen kanssa. Kehittämistehtävän tuloksena on yritykselle suunnattu raportti, joka sisältää mm. työnkäyttö- ja talouslaskelmia. Tehtävien aiheina on ollut mm. sopimuspohjaisen yhteistyön kehittäminen maatalousyhtymässä, ravihevosten valmennustoiminnan yhteistyöverkostojen kehittäminen ja hiehonkasvatuksen ulkoistaminen lypsykarjatilalla.

Oppimismenetelmällä saavutetaan monipuolisia ja matkan aikana kehittyviä malleja yrityksille. Yritys ja tiimi kehittyvät sekä oppivat usean kuukauden yhteisen työskentelyn aikana. Opiskelijan tieto rakentuu tiimissä, kun asioita pohditaan ja työstetään yhdessä projektimaisesti työskennellen. Työelämätaidot kehittyvät monipuolisesti ja työelämässä tärkeän tiimimäisen toimintatavan hallitseminen vahvistuu tehtävän myötä. Opiskelija saa uusia näkemyksiä kehittämistehtävästä, yrityksestä ja tiimin jäseniltä. Kehittämistehtävien aikana kasvatetaan myös omia verkostoja sekä itsenäisesti että muiden tiimin jäsenten tai tiimien kautta. Opettajan roolina on toimia konsulttina ja rohkaista tiimiä oppimaan projektista sekä varmistaa, että tiimi toimii.

Luonnonvara-alan ylempiä ammattikorkeakouluopintoja on toteutettu Savonia-ammattikorkeakoulussa esitellyllä mallilla vuodesta 2007 kehittäen toimintaa ja aiheita palautteen mukaan. Toimintatapa on saanut erittäin hyvää palautetta niin opiskelijoilta, työelämältä kuin kohdeyrityksiltäkin.

Asiasanat: koulutus, tiimityöskentely, työelämälähtöisyys, yhteistoiminnallinen oppiminen, ylemmät ammattikorkeakoulututkinnot. 


\section{Johdanto}

Ylempi ammattikorkeakoulututkinto on ammatillista osaamista syventävä koulutus, johon voi hakeutua soveltuvan ammattikorkeakoulututkinnon tai muun alemman korkeakoulututkinnon ja kolmen vuoden työkokemuksen jälkeen. Tutkinto on vastaa Eurooppalaisessa tutkintojen viitekehyksessä (EQF) tasoa 7 (OKM 2015). Ylemmän AMK-tutkinnon tavoitteena on antaa opiskelijalle laaja-alaiset käytännölliset perustiedot ja -taidot sekä teoreettiset perusteet toimia työelämässä oman alan asiantuntijatehtävissä, valmiudet seurata ja edistää oman ammattialan kehittymistä, edellytykset oman ammattitaidon kehittämiseen ja elinikäiseen oppimiseen ja riittävä viestintä- ja kielitaito oman alan tehtäviin sekä kansainväliseen toimintaan ja yhteistyöhön (OKM 2015). Suomenkieliset tutkintonimikkeet muodostuvat lisäämällä ammattikorkeakoulun tutkintonimikkeen perään lyhenne "ylempi AMK”, esimerkiksi agrologi (ylempi AMK) (Ammattikorkeakoululaki 2014, 11§). Englanniksi luonnonvara-alan ylempien AMKtutkintojen tutkintonimike on "Master of Natural Resources"

Savonia-ammattikorkeakoulun tarjoaman agrologi (ylempi AMK) -tutkintoon tähtäävän koulutuksen osaamistavoitteiden taustalla on maaseutuyritysten toimintaympäristön muutokseen vastaaminen. Maaseutuyrityksissä ja niitä palvelevissa organisaatioissa vaaditaan entistä suurempien, monimuotoisempien ja uudistushakuisempien kokonaisuuksien hallintaa. Tavoitteeksi asetettiin uudistavan johtamisen, verkostomaisen työskentelyn ja teknologian hyödyntämisen taitojen parantaminen (Kuvio 1).

LUONNONVARA-ALAN YLEMPI AMMATTIKORKEAKOULUTUTKINTO: OSAAMISALUEET JA YDINOSAAMINEN

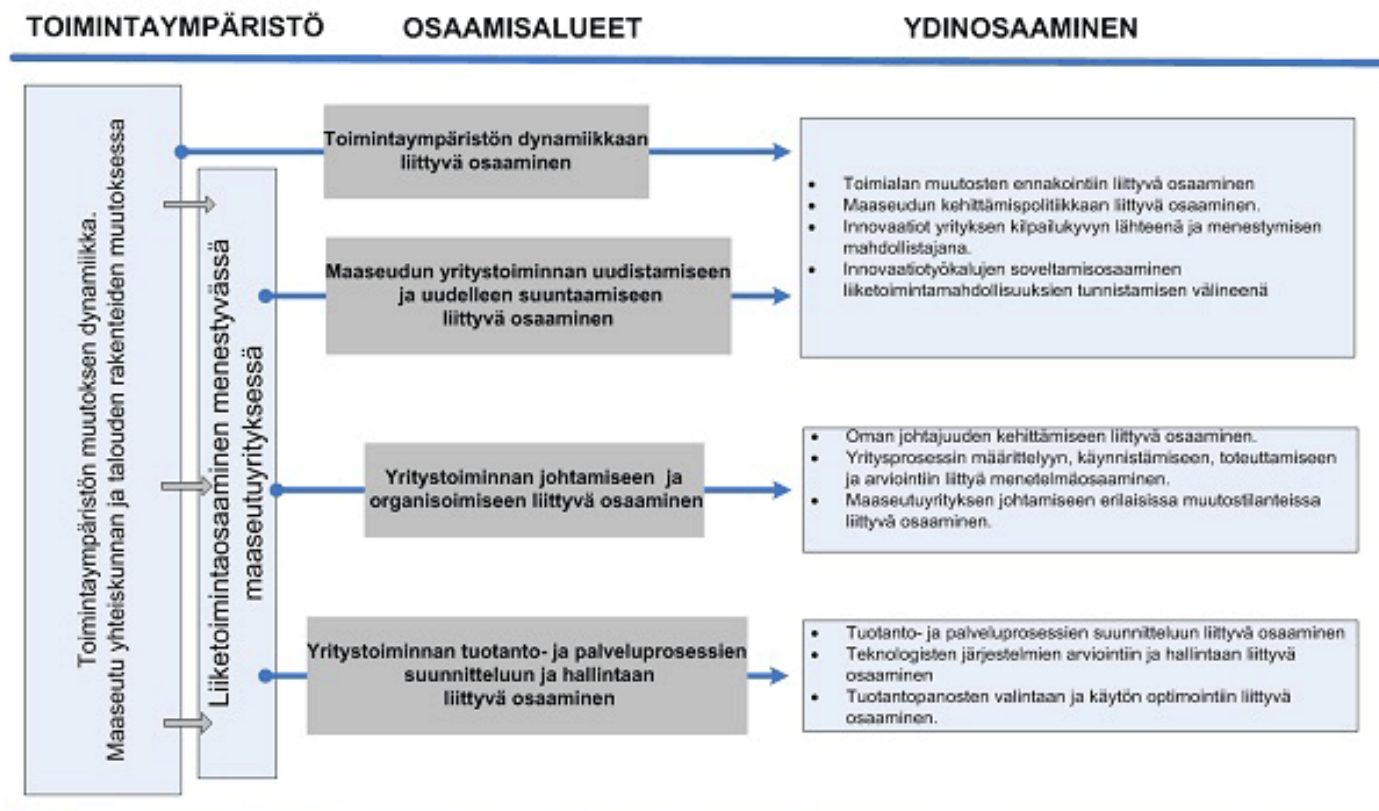

Kuvio 1. Savonia-ammattikorkeakoulun Maaseudun kehittämisen tutkinto-ohjelman tuottama osaamisprofiili. 
Savonian tarjoaa ylempänä ammattikorkeakoulututkintona Maaseudun kehittämisen tutkintoohjelmaa, jonka laajuus on 60 opintopistettä eli käytännössä noin 1,5 vuotta. Opiskelu tapahtuu yhteistoiminnallisesti tiimeissä työelämän ongelmien parissa sekä yksilöllisesti tehtävänä opinnäytetyönä (Kuvio 2). Tiimit työskentelevät yhden lukuvuoden ajan maaseutuyrityksen kehittämistehtävän parissa. Kolme opintojaksoa suoritetaan kehittämistehtävää työstämällä eli maatilan tuotannon organisointi, maaseutuyritysten yhteistyön juridiikka ja yrityksen kehitysprosessin hallinta. Kehittämistehtävää tehdään yhteistyössä kohdeyrityksen sekä muiden tiimien kanssa. Kunkin opintojakson lopputulos raportoidaan ja esitetään seminaarissa, jonne myös työelämän edustajat on kutsuttu.

Agrologi, ylempi AMK (maaseudun kehittämisen koulutusohjelma 2015 - 2016)

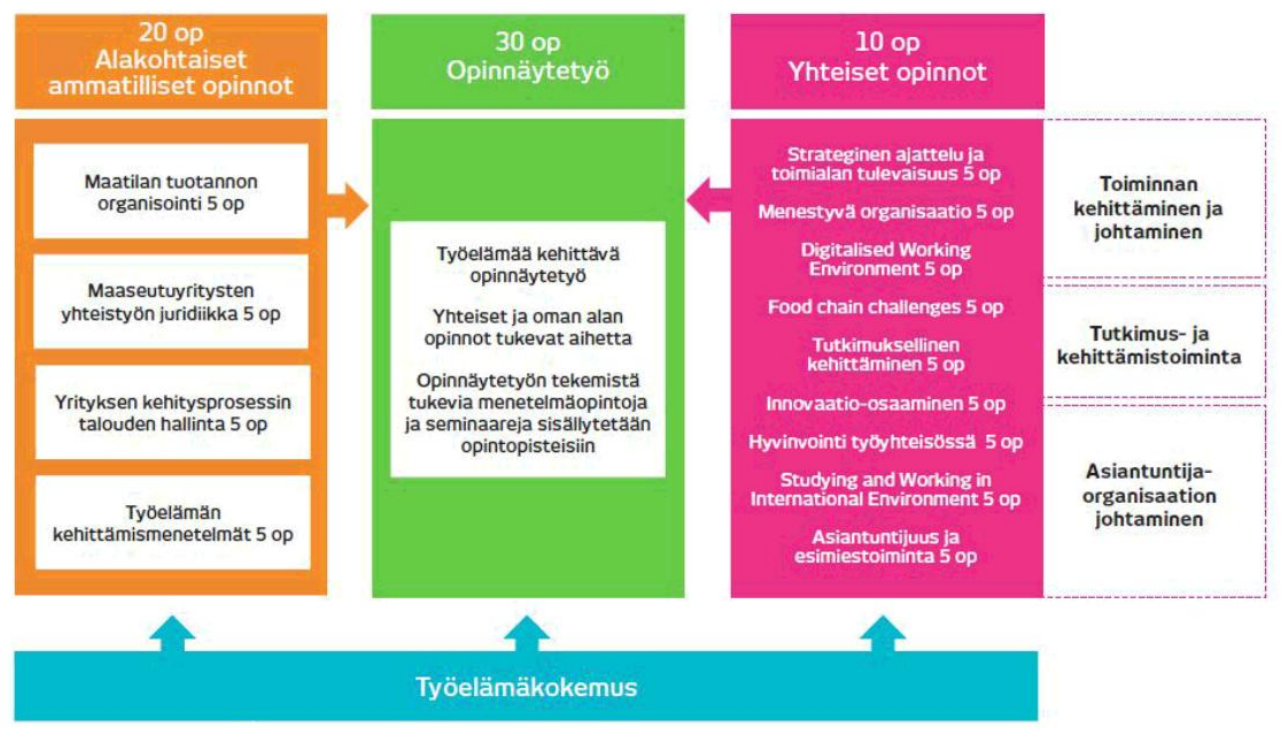

Kuvio 2. Maaseudun kehittäminen -tutkinto-ohjelman rakenne.

Maatilojen ja muiden maaseutuyritysten muutostilanteisiin liittyvän osaamisen kehittämistarpeet katsottiin tärkeiksi, joten niitä painotetaan sekä osaamisprofiilissa että tutkinto-ohjelman kompetensseissa. Monimuotokoulutuksen haasteena on usein opintojen läpäisyaste, kun opiskelijat keskeyttävät helposti opintonsa. Valitsemalla motivoiva pedagoginen malli, joka valmistaa opiskelijat alan tuleviin haasteisiin haluttiin saavuttaa tavoiteltu osaamisprofiili ja kompetenssit sekä hyvä läpäisyaste.

Tutkimuksen tavoitteena on kuvata tutkinto-ohjelman pedagogiset ratkaisut ja ratkaisuilla saavutetut tulokset ja vaikuttavuus. Vaikuttavuuden arvioimiseksi suullista palautetta on kerätty opiskelijoilta sekä työelämän edustajilta.

\section{Oppimiskäsitykset ja -menetelmät}

Maaseudun kehittämisen -tutkinto-ohjelman taustalla olevana oppimiskäsityksenä on sosiokonstruktivismi. Oppimiskäsitys painottaa erityisesti oppimisen sosiaalisia, vuorovaikutuksellisia ja yhteistoiminnallisia prosesseja (Kauppila 2007). Yksilöt rakentavat tietoa yhteisöllisesti jakamalla tietoa sekä työstämällä tietoa yhdessä muiden kanssa. Oppiminen muodostuu tilannesidonnaisesta tiedon jäsentämisestä ja käsitysten laajentamisesta. Oppijan näkökulmasta tieto kehittyy valikoimalla ja tulkitsemalla saatua informaatiota omaan aikaisempaan tietoon peilaten. Sosiokonstruktivisten näkemyksen mukaan tieto ei kuitenkaan aina ole totta, vaan sen yhteys totuuteen on suhteellinen 
(Kauppila 2007). Oppija kehittyy erityisesti kriittisessä ajattelussaan sekä yhteistoiminnallisessa oppimisessa. Opettajan roolina on varmistaa, että opiskelijan tulkinta tiedosta kehittyy oikeaan suuntaan. Lisäksi opettajan roolina on olla henkinen tuki ja valmentaja.

Maaseudun kehittämisen tutkinto-ohjelmassa oppiminen on lähes puhtaasti sosiokonstruktivistista, sillä opiskelijatiimit ratkovat laajoja käytännön ongelmia yhteistyössä. Tiimien jäsenet on valittu siten, että henkilöillä olisi mahdollisimman erilainen tausta luonnonvara-alalta (mm. hallinto, neuvonta, tutkimus). Näin opiskelijoiden osaaminen tiiminä moninkertaistuu sillä kukin jäsen tuo tiimiin oman erityisosaamisensa. Tämän vuoksi tiimien toiminnan prosessi sekä lopputulema ovat ennalta arvaamattomia ja hyvin erilaisia tiimien välillä.

Opiskelijoiden jako tiimeihin tehdään jo ennen opintojen aloittamista. Opiskelijoilta on pyydetty esittelykirje, jossa he kertovat opiskelu- ja työhistoriastaan sekä kiinnostuksensa kohteista. Näillä perusteilla ryhmä on jaettu 4 - 5 hengen tiimeihin, joissa jokainen voi toimia oman osaamisalansa asiantuntijana. Tiimi voi koostua esimerkiksi seuraavat taustat omaavista opiskelijoista:

- Opiskelija 1: Agrologi AMK, karjanhoitaja, kokemusta erityisesti lypsykarjasta, eläinten ruokinnasta ja hoidosta

- Opiskelija 2: Agrologi AMK, konemyyjä, kokemusta erityisesti maatalouskonekaupasta

- Opiskelija 3: Agrologi AMK, maataloushallinnon palveluksessa, kokemusta maataloustukijärjestelmästä sekä kunnan että ELY-keskuksen näkökulmasta

- Opiskelija 4: Agrologi AMK, tilitoimistoyrittäjä, kokemusta erityisesti taloushallinnosta ja hanketoiminnasta

- Opiskelija 5: Agrologi AMK, maatalousyrittäjä, toteuttanut omalla maatilallaan mittavan laajennusinvestoinnin

Oppimismenetelminä on hyödynnetty projektioppimista ja dialogista oppimista, jotta voitaisiin mahdollisimman jouhevasti yhdistää teoreettinen ja käytännöllinen tieto. Vesterinen (2003) selittää perinteisen oppimismenetelmien heikkouksia teorian ja käytännön erkanemisella toisistaan. Näin opiskelijalle ei muodostu koulutuksessa riittävää osaamista kohdata ja ratkaista työelämässä eteen tulevia ongelmia. Projektioppiminen mahdollistaa teorian ja käytännön yhdistämisen. Opiskelussa pyritään yhdistämään osaaminen, taidot sekä hiljainen tieto, joihin perustuu kyky kehittää ammatillista osaamistaan sekä kehittää työelämää. Ongelmalähtöisessä projektioppimisessa tavoitteena on hyödyntää opiskelijan aikaisempi kokemus ja tietämys. Uutta osaamista on kyky tunnistaa tärkeimmät ongelmat ja tietää miten niiden ratkaisemisessa tulee edetä. Projektioppimisella saavutetaan valmiuksia, jotka edesauttavat elinikäistä oppimista kuten suunnitelmallisuus, tulosvastuullisuus sekä kriittisyys (Eteläpelto et. al, 1999). Lisäksi oppimisen motivaation on todettu olevan korkeampi kuin perinteisessä opetuksessa (Vesterinen 2003).

Projektioppimissa käytettävien projektien vaateita ovat mm. (Eteläpelto et al, 1999)

- Projektien tulee olla pitkäkestoisia, mieluiten useita kuukausia.

- Projektien tulee olla lähtöisin opiskelijoille mielekkäistä ja tutuista aiheista.

- Projektien tulee tukea työelämävalmiuksien kehittämistä.

- Projektit pitää raportoida oppimistulosten todentamiseksi.

Dialogisen oppimisen käsitteessä oppijat mielletään aktiivisiksi toimijoiksi. Aarnion ja Enqvistin (2001) mukaan "Dialogi tarkoittaa ihmisten tasavertaiseen osallistumiseen perustuvaa yhdessä ajattelemista ja perehtymistä johonkin asiaan tai toimintaan." Autenttinen dialoginen oppiminen tuo puolestaan mukaan dialogin lisäksi aidot ongelmanratkaisutilanteet. Parhaimmillaan oppijat esittävät itse oppimisprosessin aikana kysymyksiä ja hakevat niihin vastauksia. Autenttista osaamisen rakentuminen erityisesti opiskelijoilla, joilla on jo työkokemusta, voidaan kuvata niin, että se yhdistää oppijan aiemman osaamisen, aidot tietolähteet ja työelämän tehtävät (Kuvio 3). Dialogiseen oppimiseen liittyy myös ajatteluprosessin etenemisen avoimuus. Opiskelijat pääsevät näkemään myös muiden prosessin ja kommentoimaan sitä. 


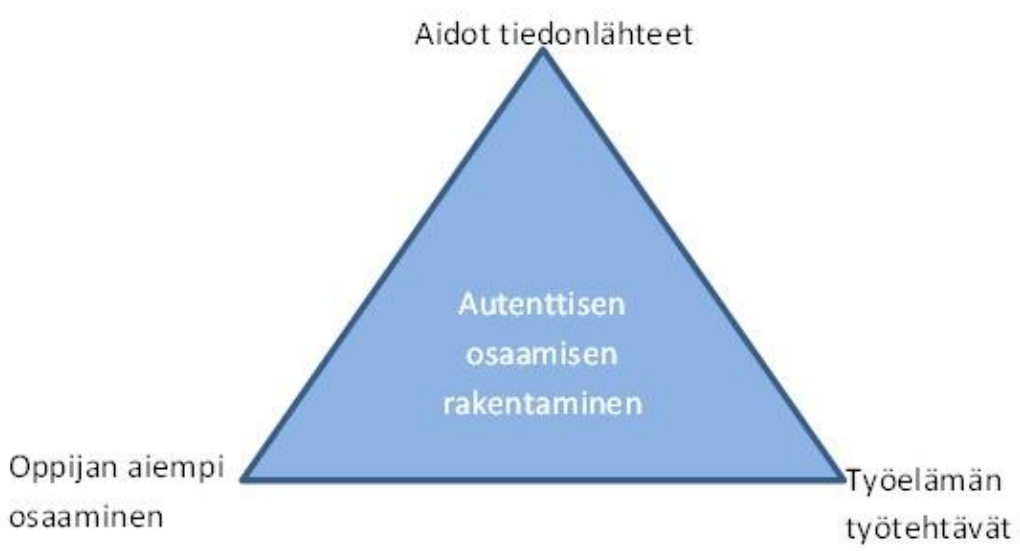

Kuvio 3. Autenttisuus oppimisessa ja osaamisen rakentamisessa ylemmässä amk-tutkinnossa (muk. Aarnio \& Enqvist 2001, 23.)

\section{Tulokset}

Savonia-ammattikorkeakoulussa lähdettiin kehittämään luonnonvara-alan ylempään ammattikorkeakoulututkintoon, agrologi (ylempi AMK), tähtäävää koulutusta projektioppimisen ja dialogisen oppimismenetelmien pohjalta. Opetuksen lähtökohdiksi otettiin vahva yhteys käytäntöön sekä maaseudun työelämän kehittämiseen. Koska opiskelijoilla on oltava vähintään kolmen vuoden työkokemus ennen opintojen aloittamista, työelämässä kertyneen osaamisen hyödyntäminen projektioppimisen keinoin katsottiin hyvin motivoivaksi menetelmäksi.

Sosiokonstruktiivisessa ajattelussa opettaja pyrkii siihen, että opiskelijat todella ymmärtävät asioita sekä sisäistävät oppimansa (Kauppila 2007). Kestävä pohja motivaatiolle on saatu luotua, kun oppiminen on opiskelijan kannalta mielekästä. Opiskelijoiden motivaatio opinnoissa on ollut korkea. Keskeyttämisiä ei juurikaan ole nähty, mikäli opintojen alkuvaihe on lähtenyt tiimin toiminnan ja projektin kannalta suotuisasti käyntiin. Henkilökohtaisissa keskusteluissa opiskelijat ovat korostaneet motivaatiotaan sekä oppimisen laajuutta. Oppia on tullut sekä työelämästä että muilta tiimin jäseniltä. Työelämän ongelmia on ymmärretty syvällisesti pohdintojen ja keskustelujen kautta.

Projektioppimisessa opettajan on luotettava siihen että opiskelijat huolehtivat omasta oppimisestaan (Vesterinen 2003). Oppimisprosessin sujuvuutta ja tiimien työskentelyä on tarkkailtu sekä lähijaksoilla että verkko-oppimisympäristössä. Tiimit ovat lähes poikkeuksetta toimineet innokkaasti ja tiedon määrä on kasvanut valtavasti prosessin aikana. Opiskelijoille on korostettu heidän vastaavan tuloksista ensisijaisesti kohdeyritykselle ja toissijaisesti omalle tiimilleen. Oppimismenetelmän sisäistäminen on ollut alkuvaiheessa opiskelijoille hankalaa, koska on totuttu siihen että oppimistehtäviä tehdään opettajalle. Käytetyssä mallissa opettaja on taustalla ohjaamassa ja rohkaisemassa, mutta tehtäviä tai esityksiä ei suunnata opettajalle. Muun muassa poissaoloista on ilmoitettu ensisijaisesti opettajalle, vaikka oikeampi kohde on oma tiimi. Opintojaksojen lopussa pidettävissä tiimikohtaisissa arviointikeskusteluissa on voitu keskustella myös tiimin jäsenten roolista ja panoksesta kehittämistehtävän tekoon. Arviointia varten opiskelijat tekevät sekä itsearvioinnin että tiimiarvioinnin, jota opettajat voivat hyödyntää arviointiprosessissa.

Dialogisuutta opiskeluun on saatu luontevasti tiimityöskentelyn kautta. Tiimityöskentely on nykyisin työelämässä yleinen työskentelymalli, joten sen oppiminen osana substanssiosaamisen syventämistä katsottiin tärkeäksi. Tiimityöskentelytaitojen kehittäminen edistää osaltaan opiskelijan valmistautumista työelämän ongelmien ratkomiseen yhteistoiminnallisesti.

Projektioppimisen tärkeitä vaiheita ovat Etäpellon ym. (1999) mukaisesti dialogi, reflektio, palaute ja arviointi. Dialogisuutta ja reflektiota on luotu oppimistilanteisiin myös tiimien välisiin 
keskusteluihin kannustamalla. Tiimien sisäinen ja välinen yhteistyö kertoo hyvästä motivaatiosta. Keskustelut ovat olleet vilkkaita sekä avoimia ja tiimit ovat kiinnostuneita toistensa kehittämistehtävistä. Kukin on tuonut omaa osaamistaan myös muiden tiimien kehittämistehtäviin. Kaikki tiimit ovat saaneet tasapuolisesti palautetta toisilta tiimeiltä sekä opettajilta. Opintojakson päätösseminaareissa ovat mukana myös työelämän edustajat kehittämistehtävän kohteena olevista yrityksistä.

Jotta ylemmän korkeakoulututkinnon osaamisvaatimukset täyttyisivät, tulee tiimin työskentelyn tavoitteet olla riittävän korkealla. Dialogisen oppimisen periaatteiden mukaisesti opiskelijatiimit saavat aidot työelämän kehittämiskohteet. Koska kyseessä on maaseudun kehittämisen tutkinto-ohjelma, jonka osaamisprofiilissa painotetaan maaseudun muutostilanteissa toimimista, kehittämiskohteiksi valittiin tiloja, joilla on suunnitteilla merkittävä toiminnan muutostilanne. Kehittämiskohteena on ollut tiloja, jotka suunnittelevat tuotantonsa moninkertaistamista tai tuotantosuunnan muutosta. Kahden edellisen toteutuksen aikana kohdeyrityksillä on myös ollut tarve strategiseen yhteistyöhön jollain sektorilla, jolloin opinnoissa painotetaan myös yhteistyön juridiikkaa ja sopimuksia.

Opiskelijat tuottavat opintojensa aikana kohdeyritykselle kuvauksen yrityksen nykytilanteesta, sisältäen tuotantoprosessien ja materiaalivirtojen kuvauksen sekä työnkäyttölaskelman. Kehittämissuunnitelmia tuotetaan vähintään kaksi ja niissä kuvataan myös tuotantoprosessit, materiaalivirrat sekä työnkäyttö. Kehittämissuunnitelmassa myös määritellään, millaista yhteistyötä yrityksen olisi järkevää tehdä. Juridiikkaan keskittyvällä opintojaksolla lopputuotoksena on ehdotus yrityksen yhteistyöstä toisen yrityksen kanssa sekä sopimusmalleja. Yrityksen kehittämisprosessin talouden hallintaan keskittyvässä opintojaksossa tuotetaan kehityssuunnitelmia ja riskianalyyseja erityisesti talouden näkökulmasta.

\section{Johtopäätökset}

Maaseudun kehittämisen tutkinto-ohjelmaa on pyöritetty seitsemän vuotta valitulla pedagogisella mallilla. Opiskelijapalaute ja kohdeyritysten antama palaute kehittämistehtävistä on ollut erittäin positiivista. Opiskelijat ovat pitäneet oppimisympäristöä motivoivana, kunhan alkuhankaluuksista liittyen tiimin toimintaan sekä erilaiseen työskentelytapaan on päästy ylitse. Työelämän edustajat arvostavat tutkinnon suorittaneiden opiskelijoiden osaamista. Erityisesti on korostettu tiimimäisten työskentelytaitojen kehittymistä sekä ongelmaratkaisutaitojen kehittymistä. Pedagoginen malli on toimiva ylemmän ammattikorkeakoulututkinnon kaltaisissa tutkinto-ohjelmissa.

Ylempi AMK-tutkinto on vielä suhteellisen tuntematon työelämässä. Tutkinnon suorittaneet opiskelijat ovat nousseet monessa organisaatiossa esimiestehtäviin, joten ymmärrys tutkinnon laadusta tulee kasvamaan ja vaikutus rekrytoinnissa lisääntyy.

\section{Kirjallisuus}

Aarnio, H. \& Enqvist, J. 2001. Dialoginen oppiminen verkossa - DIANA-malli ammatillisen osaamisen rakentamisen rakentamiseen. Kehittyvä koulutus 2/2001. Opetushallitus: $70 \mathrm{~s}$.

Ammattikorkeakoululaki. 932/2914. Finlex. Lainsäädäntö [Viitattu 2015-12-13]. Saatavissa: http://www.finlex.fi/fi/laki/ajantasa/2014/20140932

Eteläpelto, A. \& Rasku-Puttonen, H. 1999. Projektioppimisen haasteet ja mahdollisuudet. Teoksessa A. Eteläpelto \& P. Tynjälä (toim.), Oppiminen ja asiantuntijuus. Työelämän ja koulutuksen näkökulma, 181-205. Juva: WSOY.

Kauppila, R. 2007. Ihmisen tapa oppia. PS kustannus: 207 s.

OKM 2014. Ammattikorkeakoulut. Opiskelu ja tutkinnot. [Viitattu 2015-12-13]. Saatavissa:

http://www.okm.fi/OPM/Koulutus/ammattikorkeakoulutus/opiskelu_ja_tutkinnot/?lang=fi

Tynjälä, P. (1999). Oppiminen tiedon rakentamisena - konstruktivistisen oppimiskäsityksen perusteita. Tampere: Tammer-Paino Oy.

Vesterinen, J. 2003. Projektioppiminen - ohjaajan käsikirja. Hämeen ammattikorkeakoulu. Ammatillinen opettajakorkeakoulu. Opinnäytetyö. 